\title{
Kritika antinomija kao opravdanja uobičajene interpretacije Kantove epistemologije
}

\author{
Hrvoje Juko*
}

\begin{abstract}
Sažetak
Transcendentalna idealnost predmeta naše spoznaje bitna je sastavnica Kantove epistemologije - barem njezine uobičajene interpretacije. U članku se tvrdi da (upravo zbog teze o transcendentalnoj idealnosti) uobičajena interpretacija Kantove epistemologije (UIKE) plauzibilno pati od problema nekoherencije i nije jasno opravdana. Na tvrdnju da antinomije daju opravdanje za UIKE u članku se odgovara da bi onda barem jedna antinomija morala biti racionalno-kompulzivna. Međutim nijedna nije. Stoga se zaključuje kako UIKE nije opravdana antinomijama $i$ - ako su antinomije jedino opravdanje za UIKE - onda ona nije opravdana.

Ključne riječi: Immanuel Kant, Kritika čistoga uma, transcendentalni idealizam, uobičajena interpretacija Kantove epistemologije, antinomije, racionalna kompulzivnost, opravdanje
\end{abstract}

\section{Uvod}

Antinomije se nekad uzimaju kao opravdanje za važnu tezu Kantove (ili bilo koje kantolike) epistemologije: da su predmeti naših spoznajnih čina transcendentalno idealni (tj. ovisni o nama za svoju stvarnost i strukturu), premda su empirijski stvarni (tj. stvarno su dijelovi našeg iskustva) (Plantinga, 2000, 31-32).

Moj džepni nožić empirijski je stvaran. Stvarno imam iskustvo dodira džepnog nožića: hladan je i gladak. Imam iskustvo gledanja džepnog nožića: crven je i siv itd. Moj džepni nožić empirijski je stvaran. Ali istovremeno je transcendentalno idealan. Sva ta iskustva — njegova tekstura, boja i dr. — ovise o meni (epistemičkom subjektu) za svoju strukturu i stvarnost. Zbog specifičnog načina kako je moj spoznajni aparat ustrojen, imam iskustvo nožića kakvo već imam (hladan, gladak, crven i siv) i zbog specifičnog načina kako je moj spoznajni aparat ustrojen, uopće imam to iskustvo.

Ako mi svoj um upotrijebimo ne samo za primjenu razumskih načela na predmete iskustva, nego ako se odvažimo da ta načela protegnemo preko granica iskustva, onda

* Hrvoje Juko, univ. bacc. phil, Pontificia Università Gregoriana. Adresa: Piazza della Pilotta 4, 00187 Rim, Italija. E-pošta: hrvoje_juko@yahoo.com 
nastaju sofistički teoremi. Oni se u iskustvu ne smiju nadati ni potvrdi niti se moraju bojati opovrgnuća, pa ne samo da je svaki od njih sam o sebi bez proturječja, nego čak u prirodi uma nalazi uvjete svoje nužnosti, samo što nesrećom i antiteza ima na svojoj strani isto tako vrijedne i nužne razloge tvrdnje (Kant, 1984, 207; A421, B448-449).

Čini se da Kant tvrdi nešto poput sljedećeg: ako razumijem da se moja spoznaja odnosi samo na predmete iskustva (da se »razumska načela primjenjuju samo na predmete iskustva «), na to kako su mi stvari dane u iskustvu, onda nemam problema sa spoznajom. Epistemička je mreža zdrava. Znam samo što mi je dano u iskustvu, a to kakve su stvari u sebi (i postoje li uopće) ne mogu znati. Ako bih pak pomislio da se moja spoznaja odnosi na stvari kakve su po sebi ili neovisno o mojem iskustvu njih (»razumska načela protegnuti preko granica iskustva «) — onda upadam u probleme sa spoznajom. Epistemička mreža nije zdrava. Zašto? Jer pod tom pretpostavkom (pretpostavkom spoznajnog realizma) nastaju »sofistički teoremi«; tvrdnje koje »u prirodi uma« nalaze jednaku potvrdu i negaciju. Drugim riječima, dobivam proturječja u svojoj epistemičkoj mreži - i to proturječne teze jednako (maksimalno) opravdane ili uvjerljive. I potvrda i negacija sofističkih teorema, kako kaže Kant, »u prirodi uma« nalaze »uvjete svoje nužnosti« te imaju jednako »vrijedne i nužne razloge tvrdnje«.

Kao rješenje tog problema, trebamo zanijekati pretpostavku spoznajnog realizma i zaključiti da predmeti naše spoznaje ipak nisu neovisni o nama u postojanju i strukturi. To jest, da su transcendentalno idealni. Dostupni su mi samo fenomeni, a o strukturi i stvarnosti stvari neovisno o mojim spoznajnim činima ne mogu ništa znati.

Da bi Kantova konkluzija slijedila, međutim, i teza i antiteza barem jedne od antinomija mora biti racionalno kompulzivna. ${ }^{1}$ Što mislim kad kažem da je neki iskaz racionalno kompulzivan? Mislim reći kako je takav da bi njegovo neprihvaćanje povlačilo iracionalnost za osobu koja ga ne prihvaća. Drugim riječima, ako je $\mathrm{P}$ racionalno kompulzivan i ja razumijem $\mathrm{P}$ i ne prihvaćam $\mathrm{P}$, onda sam iracionalan. Imam nekakav defekt u svojoj mreži vjerovanja.

U slučaju Kanta i antinomija to znači sljedeće: osoba koja razumije svaku od premisa dane antinomije, ako je racionalna, mora prihvatiti konkluziju. U su-

1 Zašto racionalno kompulzivna, a ne samo dobar argument? Prvo, zato što se čini da Kant tako kaže (»sofistički teoremi«). Drugo, zato što samo dobri argumenti za kontradiktorna stajališta neće pomoći Kantovoj epistemologiji. Čini se očitim da osoba može imati jako dobre razloge i za $\mathrm{P}$ i ne-P, a da pritom ne može ništa opravdano zaključiti o strukturi svojeg spoznavanja. Osoba koja je inače pouzdana tvrdi da trebam skrenuti lijevo, dok druga koja je jednako pouzdana tvrdi da trebam skrenuti desno kako bih došao do bolnice. Mogu li iz toga stvarno, osim u šali, zaključiti da predmeti moje spoznaje ovise o meni u svojoj strukturi i stvarnosti? Imam jako dobrih razloga prihvatiti intuicionizam, kao što imam jako dobrih razloga prihvatiti platonizam. Ide li tu išta u korist transcendentalnom idealizmu? Teško. Možda bi se moglo tvrditi da je transcendentalni idealizam najbolje objašnjenje toga što imamo — ako ne racionalno kompulzivne — onda barem vrlo dobre argumente za tezu i antitezu u određenim problemima. Ali to - osim što ovisi o tome da su barem jedna teza i antiteza dobri argumenti — čini se daleko pretjeranim. Ne bi li bolje i daleko manje egzotično objašnjenje bilo da naša epistemička situacija jednostavno nije povoljna u svezi s P, a ne da se naša spoznaja zapravo ne odnosi na stvari kakve su po sebi? Transcendentalni se idealizam čini kao lov na patke nuklearnim oružjem. Pretjerano. 
protnome njezina je mreža vjerovanja na neki način defektna ili neispravna - ne ostvaruje epistemičku izvrsnost, ispravnu funkciju ili slično.

Prilično je jasno da nijedna od antinomija koje Kant u Kritici čistoga uma navodi nije teorem u logičkom smislu riječi — iskaz s dokazom bez pretpostavki ili koji slijedi iz aksioma. Stoga uzimam da Kant misli, šire, argument koji je racionalno kompulzivan. U ovom članku argumentirat ću za dvoje: 1. nijedna od Kantovih antinomije nije racionalno kompulzivna; 2. neke od teza i antiteza Kantovih antinomija nisu čak ni dobri argumenti.

\section{Kantova epistemologija i opravdanje}

\section{Uobičajena (školska) interpretacija Kanta je sljedeća:}

Postoje dva svijeta predmeta; naše iskustvo je samo jedan svijet, svijet fenomena koji ovise o nama za svoju egzistenciju; ako bismo mi prestali postojati, i oni bi. To je zbog toga što mi fenomenalni svijet na neki način konstruiramo od onoga što nam je dano, podataka, sirovog materijala [osjetilnog] iskustva. Noumenalni svijet, međutim, nije tako ovisan o nama, ali je uz to i takav da o njemu nemamo zora, nemamo nikakvog direktnog iskustva njega. Konačno, postoji ipak veza između dva svijeta u nečemu poput kauzalne transakcije između noumena i transcendentalnog ega (koji je sam noumenon) koji u nama iz [osjetilnih] datosti proizvode fenomenalni svijet (Plantinga, 2000, 22). ${ }^{2}$

Da se vratimo primjeru džepnog nožića: sve čemu imam spoznajni pristup je fenomen nožića; kako mi je prisutan u osjetilnom iskustvu (hladan, siv i neukusan). Taj fenomen moja je konstrukcija. I to konstrukcija iz sirovog materijala osjetilnog iskustva. Postoji li nekakav stvarni nožić (ili bilo što tomu slično) iza fenomena, nešto što uzrokuje fenomen, nije mi dostupno. Osim toga, na stvari po sebi (ili Dinge an sich) moji se koncepti ne mogu primijeniti i ne mogu na njih referirati. Nema epistemičkog pristupa, nema primjene koncepata, nema referiranja - sve te radnje odnose se na fenomene; na produkt konstrukcije iz materijala osjetilnog iskustva. O tome što su Dinge an sich (i postoje li), ja sam u mraku. Čini se da Kant to tvrdi kad kaže da »nam predmeti o sebi uopće nisu poznati« (Kant, 1984, 38; A30, B45). O njima nemamo zora, a bez zora primjenjivanje kategorija (poput uzrok-učinak) na njih nema smisla ili sadržaja (usp. Kant, 1984, 134; A239, B298).

Međutim s tom slikom postoje značajni problemi koherencije. Kao što Alvin Plantinga ističe:

Moramo se sjetiti kako se čitava ta shema [...] čini nekoherentnom [...] Onaj tko izlaže i predlaže tu shemu čini više tvrdnji o Dinge [an sich]: da nisu u prostoru i vremenu primjerice, i značajnije, da se naši koncepti ne mogu primijeniti na njih (primjenjuju se samo na fenomene), tako da ne možemo referirati na njih ili misliti o njima. Ali ako stvarno ne možemo pomišljati Dinge [an sich], onda ih ne možemo pomišljati (i ne možemo ih ni fićukati); ako ih ne možemo pomišljati, ne možemo ni doći na pomisao da takvih stvari ima. Nekoherencija je očita (Plantinga, 2000, 38).

2 Svi prijevodi s literature na engleskom jeziku za potrebe članka su moji. Dodaci u uglatim zagradama su naznake ispuštenoga teksta radi kratkoće ili pak moji umetci radi jasnoće. 
Čak i ako je Kantova tvrdnja značajno slabija od tog opisa; ako ipak imamo nekakav epistemički pristup stvarima u sebi; ako na njih možemo na neki način referirati i ako se naši koncepti na njih ipak nekako mogu primjenjivati, ali da svejedno o njima ne možemo ništa pozitivno znati (Stang, 2016), svejedno ostaje problem Kantova pripisivanja kauzalnih uloga stvarima u sebi, što je zasigurno pozitivno znanje. No čak i da zanemarimo problem koherencije, koja opravdanja daje Kant za tako radikalan pogled na ljudsku spoznaju? Bio bi potreban neki snažan argument da bi se takva slika kao što je uobičajena interpretacija Kanta učinila plauzibilnom. Problem je taj što u Kritici nije očito koji bi to argument trebao biti.

Međutim, ako je Kant u pravu da pod pretpostavkom mogućnosti referiranja na Dinge an sich možemo racionalno kompulzivno dokazati u četiri slučaja i tezu i antitezu, onda bismo imali neizravan dokaz (njih četiri) da ne možemo referirati na Dinge an sich i da trebamo ograničiti našu spoznaju na područje iskustva i fenomena — za transcendentalni idealizam. Primjerice:

a) Možemo misliti o i referirati na Dinge an sich.

b) Svijet je počeo postojati u vremenu.

c) Svijet nije počeo postojati u vremenu.

d) Ne možemo misliti o i referirati na Dinge an sich. $\quad(\mathrm{a}-\mathrm{c}, \mathrm{u} \neg)$

Jesu li, onda, Kantove antinomije uspješne? Kako bismo mogli odgovoriti na to pitanje, moramo za tezu i antitezu svake antinomije pitati jesu li valjani argumenti te je li svaka od premisa takva da ju se ne može racionalno zanijekati. ${ }^{3}$

\section{Prva antinomija: početak svijeta u vremenu}

Teza prve antinomije glasi: »Svijet ima početak u vremenu, a s obzirom na prostor također je ograničen granicama«. Jednostavnosti radi, pogledajmo samo dio argumenta koji se tiče vremenskog početka. Primjedbe o prostoru imale bi sasvim paralelne konture. Argument ide ovako:

Jer uzmimo da svijet u pogledu vremena nema početka, onda je do svakoga danoga časa protekla vječnost, a prema tome beskonačan niz stanja stvari u svijetu koja slijede jedno za drugim. No beskonačnost jednoga niza sastoji se upravo u tome da sukcesivnom sintezom nikada ne može biti dovršen. Prema tome je nemoguć beskonačni svjetski niz koji je protekao, dakle početak je svijeta nuždan uvjet njegove opstojnosti, a to je najprije valjalo dokazati (Kant, 1984, 209; A427, B455).

Riječ je o reductio ad absurdum. Jedna od premisa je: beskonačan niz nikada ne može biti dovršen sukcesivnom sintezom. Kant nemogućnost dovršavanja sukcesivnom sintezom uzima za definirajuću oznaku beskonačnoga niza. ${ }^{4}$

3 Ako neku od premisa argumenta možemo racionalno zanijekati, onda konkluzija nije racionalno kompulzivno uspostavljena tim argumentom.

4 Suvremena teorija skupova definira skup kao beskonačan samo ako ima pravi podskup koji se s njim može staviti u bijekciju ili 1-1 odnos. Drukčije rečeno - ako skup ima pravi i jednakobrojni podskup. Međutim, suvremena teorija skupova slaže se s Kantom da je rezultat dodavanja ko- 
Međutim, ako je prošlost beskonačna, onda je do sadašnjeg trenutka prošla beskonačnost trenutaka. Budući da trenutci nisu „svi dani odjednom“, nego se niz trenutaka formira sekvencijalno, zbivanjem jednoga nakon drugoga, niz je trenutaka formiran susljednim dodavanjem (sukcesivnom sintezom). Ali, rekli smo da beskonačan niz ne može biti tako formiran. Stoga negiramo pretpostavku pod kojom smo dobili proturječje (Svijet nema početka u vremenu) i zaključujemo da svijet ipak ima početak $u$ vremenu.

No, konkluziju je moguće blokirati. Kant pretpostavlja dinamičnu ili A-teoriju vremena, prema kojoj je vremensko postajanje stvarno te — kako smo rekli — vremenski se niz trenutaka sekvencijalno formira zbivanjem jednog trenutka nakon drugog. Ali ako je vrijeme statično ili ima B-teoretsku narav, onda neće biti nikakve sukcesivne sinteze.

Po B-teoriji ili statičnoj teoriji vremena, prema kojoj je vremensko postajanje iluzija, vrijeme je analogno dimenziji prostora; nema nikakvog prolaska iz jednog trenutka u drugi te stoga nikada neće biti sinteze, nego će čitav zbir vremenskih trenutaka postojati simultano, poput prostorno-vremenskog bloka. Kant bi mogao argumentirati da je A-teorija vremena plauzibilnija, ali teško je — barem bez ozbiljnog argumentativnog napora, koji kod Kanta ne nalazimo - tvrditi kako je B-teoretičar jednostavno iracionalan. Jedna od najpopularnijih interpretacija Specijalne teorije relativnosti uključuje upravo B-teoriju vremena. ${ }^{5}$ Jesu li fizičari koji je prihvaćaju - uključujući takva imena kao što su Mikowski, Einstein i Grünbaum — stvarno svi odreda iracionalni? Ako je moguće racionalno kompulzivno eliminirati B-teoriju, to ne nalazimo u Kritici.

No, vratimo se argumentu za tezu pod pretpostavkom A-teorije ili dinamične teorije vremena. Poprilično je jasno kako niz ne može biti formiran susljednim dodavanjem ako počnemo od neke konačne količine i potom nastavimo do beskraja dodavati. Recimo da odlučite prebrojati sve prirodne brojeve i počnete $s$ 1. Koliko god dugo dodavali, uvijek možete dodati veći broj. Kardinalni broj beskonačnog skupa $\aleph_{0}$ nema prethodnika i stoga ne može biti formiran susljednim dodavanjem. ${ }^{6}$ Jedini način kako bi mogao postojati takav beskonačan niz je da jednostavno bude postavljen, čitav, odjednom.

Nekad se tvrdi da je moguće formirati beskonačan niz susljednim dodavanjem ako nikada ne počnemo - to jest, ako oduvijek, od beskonačnosti dodajemo i završimo u nekom trenutku. Budući da je beskonačna prošlost baš takav niz — koji nikada nije počeo, nego oduvijek traje, onda može biti formiran sukcesivnom sintezom (Mackie, 1982, 93; Sobel, 2004, 182; Swinburne, 1968, 298-299). Kant je u svojem argumentu krivo pretpostavio neku beskonačno udaljenu točku

načnih skupova uvijek konačan skup. Susljednim unijama konačnih skupova ne možemo dobiti beskonačan skup (Abian, 1965, 249).

5 Za kratki pregled tri fizikalne interpretacije Specijalne teorije relativnosti vidi: Craig, 2007, 11-49.

6 To je istinito čak i da smanjujemo intervale dodavanja (primjerice da prvi broj dodamo nakon 1 sekunde, drugi nakon pola sekunde, treći nakon četvrtine itd., i nakon dvije sekunde bi, navodno, trebali imati formiran beskonačan niz). Više o apsurdnostima koje generiraju tzv. super-zadatci vidi u poglavlju o Zenonovim paradoksima u: Craig, 1979, 175-188. 
u prošlosti, od koje bi počeli dodavanje trenutaka. Ali ako je prošlost beskonačna, onda nema nikakve, čak ni beskonačno udaljene točke u prošlosti odakle bi počeli dodavanje; nego jednostavno oduvijek dodajemo. Kant je ipak u krivu.

Ili nije. Kant nigdje u gornjem argumentu ne pretpostavlja neku točku u prošlosti — čak ni beskonačno udaljenu — od koje bi se počelo prolaziti kroz trenutke da bi se stiglo do sadašnjosti. Činjenica da takve točke nema uopće ne pomaže slučaju protiv Kanta. Tvrditi da je moguće nikada ne početi i završiti beskonačni niz je poput tvrdnje da je moguće prebrojiti sve negativne brojeve, završivši s nulom, samo ako nikada ne počnemo, nego ako oduvijek odbrojavamo. Zamislite čovjeka koji od beskonačnosti prebrojava sve negativne brojeve i čujete ga kako završava: »...-3, $-2,-1,0$ ! « Ali to se čini apsurdnim. Ako ih prebrojava od beskonačnosti, zašto je završio baš sada? U bilo kojem prošlom trenutku proteklo je jednako vremena kao do sada - beskonačno vremena. Tako da bi u bilo kojem prošlom trenutku trebao biti gotov. Nikada ga ne bismo mogli naći da broji, nego bi u svakom trenutku prošlosti već završio svoje prebrojavanje. Oduvijek bi bio gotov, što proturječi pretpostavci.

Stoga se teza Kantove antinomije čini plauzibilnom, iako nismo sigurni da je racionalno kompulzivna na temelju onoga što imamo u Kritici.

Antiteza prve antinomije glasi: »Svijet nema početka i granica u prostoru, nego je beskonačan kako u pogledu vremena, tako i prostora «. Dokaz je ovaj:

Jer pretpostavimo da [svijet] ima početak. Kako je početak opstojnost, kojoj prethodi vrijeme u kojemu stvar nije bila, to mora da je prethodilo i vrijeme u kojemu svijet nije bio, tj. prazno vrijeme. No u praznome vremenu nije moguć postanak neke stvari, jer ni jedan dio takva vremena nema na sebi nikakvoga uvjeta opstojnosti, po kojemu bi se razlikovao od dijelova vremena neopstojnosti (bilo da se prihvaća, da je svijet nastao sam od sebe ili pomoću nekog drugog uzroka). Dakle u svijetu može doduše započeti mnogi niz stvari, ali sam svijet ne može imati početka, pa je prema tome u pogledu prošloga vremena beskonačan (Kant, 1984, 209; A426, B455).

Opet je riječ o neizravnom argumentu. Ako kažemo da je svijet počeo postojati, onda je moralo biti neko vrijeme prije nego je postojao, a to vrijeme je prazno vrijeme. U njemu ništa ne može početi postojati jer ništa ne razlikuje u uvjetima jedan od drugog praznog trenutka. Stoga svijet nije počeo postojati. Pretpostavke bi bile sljedeće:

(1) Za svaki događaj ili stvar koja je počela postojati, postoji vrijeme kada taj događaj nije bio ili stvar nije postojala.

(2) U praznom vremenu (vremenu u kojem ništa ne postoji) ništa ne bi moglo početi postojati jer ne bi bilo razloga da nastane u jednom dijelu praznog vremena, a ne u drugom.

Nijedna nije kompulzivna. Štoviše, malo tko bi branio prvu pretpostavku s obzirom na svijet, nego bi se tipično tvrdilo da svijet počinje postojati s nastankom vremena, uz analizu toga poput ove: svijet je počeo postojati ako postoji trenutak $t_{0}$ kada svijet postoji, $t_{0}$ je prvi trenutak postojanja svijeta i ne postoji ni jedan prethodni (A-teoretski ili B-teoretski) trenutak vremena. To je, konačno, ono što suvremeni kozmolozi misle pod izrazom „početak svemira“. 
Pretpostavka (2) nije bolja. Ako Bog postoji i ima slobodnu volju, onda je mogao sasvim proizvoljno odlučiti u bilo kojem od praznih trenutaka kada stvoriti svijet, na jednak način na koji bi neki slobodni djelatelj, sjedeći od beskraja naovamo u bilo kojem trenutku mogao proizvoljno odlučiti ustati. To je uočio još al-Ghazali s dugom tradicijom koja prepoznaje slobodnu volju upravo u mogućnosti arbitrarnog izbora (tj. izbora koji ne ovisi o prevladavajućim razlozima) u slučajevima potpuno istovjetnih disjunkta (Craig, 1979, 150). Dokaz za antitezu stoga nije racionalno kompulzivan.

\section{Druga antinomija: složenost i jednostavnost}

Teza antinomije o složenosti glasi: »Svaka složena supstancija na svijetu sastoji se od jednostavnih dijelova i ne egzistira uopće ništa osim jednostavnoga ili onoga što je od njega složeno«. Dokaz, opet neizravan, je ovaj:

Jer uzmite da se složene supstancije ne sastoje od jednostavnih dijelova. Kad bi se onda u mislima ukinula svaka složenost, ne bi preostao nikakav složeni, a ni jednostavni dio (jer jednostavnih dijelova nema). Prema tome ne bi preostalo ništa, dakle ne bi bila dana supstancija. Ili je dakle nemoguće da se u mislima ukine svaka složenost, ili mora nakon njezina ukinuća preostati nešto što postoji bez svake složenosti, tj. mora preostati ono jednostavno. No u prvome se slučaju ono složeno ne bi opet sastojalo od supstancija (jer kod njih je složenost samo slučajna relacija supstancija bez koje one moraju postojati kao bića koja su o sebi trajna). Kako pak ovaj slučaj proturječi pretpostavci, preostaje samo drugi, naime da se supstancijalna složenost na svijetu sastoji od jednostavnih dijelova (Kant, 1984, 213; A434, B462).

Ključne premise su:

(1) Ako supstancije nisu složene od jednostavnih dijelova, onda ako se ukine u mislima svaka složenost, ne preostaje ništa.

Pod složenom supstancijom koja se ne sastoji od jednostavnih dijelova Kant vjerojatno ima na umu materijalnu supstanciju, odnosno protežnu materiju novovjekovne znanosti, napose Newton-Boyleov atomizam, koja bi bila sastavljena od dijelova, ali su dijelovi beskonačno djeljivi tako da ni jedan od njih nije jednostavan (takav da se ne može dalje dijeliti). Zamislimo sad da se u takvoj supstanciji odjednom ukine sva kompozicija. Što će ostati? Pa, samo ono što je bez kompozicije, samo ono što je jednostavno. Ali nema ničeg jednostavnoga. Ukinuće složenosti bilo bi ukinuće supstancije — i ne bi preostalo ništa.

(2) Ili je nemoguće da se ukine u mislima svaka složenost ili nakon ukinuća svake složenosti u mislima ostaje nešto jednostavno.

Ovo je neopravdano. Zašto ne bi bila moguća treća opcija: nakon ukinuća svake složenosti u mislima — u slučaju složene supstancije bez jednostavnih dijelova - ne ostaje ništa? Iz činjenice da ukinuće složenosti u takvoj supstanciji znači da ne preostaje ništa, ne slijedi da je to nemoguće.

Kant kaže da u tom slučaju »ne bi bila dana supstancija«. U jednom očitom smislu, to je točno; da nakon ukinuća sve složenosti ne bi bila dana složena supstancija slijedi analitički. Možda tom napomenom Kant želi izraziti proturječje 
pretpostavci s početka dokaza: da nam je dana složena supstancija. No, takvo razumijevanje dokaza bilo bi očito falaciozno. Supstancija na početku dokaza je dana $u z$ relaciju složenosti. Samo ako se ta relacija $u k i n e$, supstancija neće biti dana. Stoga nema proturječenja pretpostavci.

Kant u svakom slučaju pretpostavlja da je nemoguće da nakon ukinuća složene supstancije ne preostane ništa. Možda bi to mogao opravdati tvrdnjom da je relacija sastavljenosti kontingentna ili — kako kaže — »slučajna«:

(3) Kod supstancija složenost je samo slučajna relacija bez koje one postoje kao trajna bića.

Ali ako su stvari u pitanju složene i nijedan od dijelova nije jednostavan, onda se čini da je u njima relacija sastavljenosti de re nužna, a ne slučajna. Koje opravdanje bi nam mogao dati za tvrdnju o kontingenciji odnosa sastavljenosti u takvim predmetima? Možda to pretpostavlja, ali pretpostavljanje nije racionalno kompulzivno. Možda definira supstanciju kao »ono što mora postojati čak i kad se ukine kontingentna relacija sastavljenosti«, no to nije obećavajuća strategija iz barem dva razloga. Prvi smo već naveli: nije jasno zašto bi relacija sastavljenost u supstancijama bila kontingentna, a ne de re nužna. Drugi je što znamo za jasne primjere supstancija koje prestaju postojati kada im se ukine sastavljenost - poput čovjeka, računala ili stabla. Tu sigurno nije »složenost samo slučajna relacija supstancija bez koje one moraju postojati kao bića koja su o sebi trajna«.

Možda bi se moglo odgovoriti da Kant ne misli da mora nastaviti postojati ta konkretna supstancija (čovjek) kad joj se ukine jedan stupanj složenosti (relacija složenosti tkiva-stanice, recimo), nego da mora postojati barem neka supstancija čak i kad se ukine svaki stupanj složenosti. To bi izbjeglo očite protuprimjere poput gornjih, ali to svejedno ostaje kontroverzna metafizička tvrdnja za koju nije ponuđeno nikakvo opravdanje. Stoga drugu i treću premisu možemo racionalno zanijekati.

Dokaz za antitezu glasi:

Pretpostavite da se složena stvar (kao supstancija) sastoji od jednostavnih dijelova. Kako je svaki vanjski odnos, dakle i svaka složenost od supstancija moguća samo u prostoru, to se upravo od onoliko dijelova, od koliko se sastoji ono složeno, mora sastojati i prostor koji ono zauzima. Dakle svaki dio složenoga mora zauzimati jedan prostor. No apsolutno prvi dijelovi svega složenoga su jednostavni. Dakle, ono jednostavno zaprema jedan prostor. Kako pak sve ono realno što zaprema prostor obuhvaća u sebi raznolikost koja se nalazi jedna izvan druge, dakle koja je složena, i to kao nešto realno složeno ne od akcidencija (jer ove ne mogu bez supstancije biti jedna izvan druge), nego od supstancija, onda bi ono jednostavno bilo supstancijalna složenost, a to sebi proturječi (Kant, 1984, 213; A435, B463).

I taj je dokaz reductio ad apsurdum. Kant argumentira da ne mogu postojati jednostavni dijelovi jer bi oni sami morali biti složeni. Ključne premise su:

(1) Prostor koji zauzima supstancija sastavljena od jednostavnih dijelova mora se sastojati od onoliko dijelova od koliko se sastoji supstancija u pitanju, tako da svaki (jednostavni) dio složenoga zauzima jedan prostor.

»Svaki dio složenoga zauzima jedan prostor« je nedorečeno i može imati najmanje dva značenja. Poprilično je nekontroverzno da za svaki dio jednog svakodnevnog, složenog predmeta (šibice, primjerice) mora postojati neki 
prostor koji on zauzima (za taj atom postoji neki prostor koji on zauzima), ali nije nimalo očito da za svaki (jednostavni) dio takvog predmeta (kvark ili strunu, recimo) postoji jedna mjera prostora koju oni svi zauzimaju. Dalje Kant kaže:

(2) Sve realno što zauzima prostor ima u sebi raznolikost koja se nalazi jedna izvan druge i koja je stoga složena od supstancija

Tu se možda referira na skolastički nauk o partes extra partes, ali je nejasno na koji bi to način trebalo implicirati da su dijelovi stvarī sami složeni od supstancija. Dok konstituiraju supstanciju, stoje spram nje u odnosu akcidenta, premda bi izvan te konstitucije dijelovi mogli biti supstancije. Ali kako bi iz sastavljenosti trebalo slijediti da svaki dio zauzima jedan prostor kao složena supstancija? Mereološke vode su duboke i Kritika ne nudi previše svjetla.

Ako Kant s »raznolikošću koja se nalazi jedna izvan druge« misli na nešto drugo, onda bi nam bio dužan puno više argumentativnog posla da — na racionalno kompulzivan način — pokaže da sve što je jednostavno ima takvu raznolikost i da takva raznolikost povlači supstancijalnu složenost. U međuvremenu nismo nimalo iracionalni u epistemičkoj suzdržanosti spram njegovih premisa.

\section{Treća antinomija: sloboda i determinizam}

Teza antinomije o slobodi glasi: »Kauzalitet prema zakonima prirode nije jedini iz kojega se mogu izvesti cjelokupne pojave svijeta. Nužno je da se za njihovo objašnjenje prihvati još jedan kauzalitet pomoću slobode«. Dokaz ide ovako:

Neka se pretpostavi, da nema drugoga kauzaliteta osim onoga prema zakonima prirode, onda sve što se zbiva pretpostavlja neko prethodno stanje za kojim ono neminovno slijedi prema nekome pravilu. No prethodno stanje mora samo biti nešto što se dogodilo (u vremenu nastalo, jer ga prije toga nije bilo). Da je ono naime bilo oduvijek, ne bi njegova posljedica tek nastala, nego bi i ona bila oduvijek. Tako je sam kauzalitet uzroka uslijed kojega se što zbiva neki događaj koji prema zakonu prirode opet pretpostavlja jedno prethodno stanje i njegov kauzalitet, a ovo isto tako još jedno starije itd. Ako se dakle sve događa prema samim zakonima prirode, onda ima uvijek samo subalterni, a nikada prapočetak i prema tome uopće nema potpunosti niza na strani uzroka koji potječu jedan od drugoga. Međutim se zakon prirode sastoji upravo u tome da se ništa ne događa bez a priori dovoljno određenog uzroka. Tako načelo, da je svaki kauzalitet moguć jedino prema prirodnim zakonima proturječi samome sebi u svojoj neograničenoj općenitosti, pa se dakle taj kauzalitet ne može prihvatiti kao jedini (Kant, 1984, 217-218; A444-446, B472-474).

Neki od ključnih koraka su:

(1) Ako nema kauzalnosti osim prema zakonima prirode, onda za svako stanje u svijetu postoji prethodno tako da ga potpuno određuje, tj. tako da neminovno slijedi iz prethodnog.

Međutim, u postnewtonovskom dobu kvantne teorije i indeterminizma to nije očito istinito. Čak i ako u svijetu ne postoji stvarna sloboda, ne slijedi kako je svako stanje svijeta deterministički određeno prethodnim. Barem na subatomskoj razini, prethodna stanja indeterministički određuju susljedna: u pojavljivanju virtualnih čestica iz kvantnog vakuuma, radioaktivnom raspadu čestica itd. Tvrditi 
to s kvantnim fizičarom koji prihvaća kopenhašku interpretaciju ${ }^{7}$ zasigurno nije iracionalno. Čak i ako se ispostavi da je istinita neka od determinističkih interpretacija kvantne mehanike, na kojima su svi spomenuti događaji samo prividno indeterministički, dok god su indeterminističe interpretacije uopće moguće, (1) nije racionalno kompulzivno. Jesu li ostale premise bolje?

(2) Prethodno stanje mora biti nešto što se dogodilo (u vremenu nastalo, jer ga prije toga nije bilo).

To, vidjeli smo u prvoj antinomiji, bit će istinito samo na A-teoriji vremena, ${ }^{8}$ ali ne ako je vrijeme B-teoretske ili statične naravi.

Moglo bi se prigovoriti da je (2) kompatibilno i s B-teorijom jer je moguće preformulirati govor o „događanju“ u B-teoretskim terminima, tako da pod „,nastajanje“ mislimo samo nešto poput „prostor-vremenska lociranost nakon“ neke koordinate, uz određene kauzalne ili druge ontičke relacije ovisnosti. Međutim, mogućnost redukcije A-teoretskih na B-teoretske predikate je kontroverzna i — što je najvažnije — sumnjam da bi Kant prihvatio takvu redukciju. U gornjem argumentu on inzistira na »nastajanju « $\mathrm{i}$ činjenici da ono što nastaje nije »oduvijek«. U B-teoretskom svijetu, međutim, u jednom snažnom smislu sve stvari jesu oduvijek - svi trenutci postoje na jednako stvaran način i svi dijelovi prostor-vremenskog sustava supostoje kao što supostoje svi dijelovi jednog ravnala. Najprirodnije čitanje gornjeg argumenta je u terminima A-teorije i čini se vjerojatnim da Kant u njemu pretpostavlja dinamičnu narav vremena. ${ }^{9}$

Po B-teoriji zato ni sljedeći iskaz neće biti istinit:

(3) Ako se sve događa deterministički, onda uvijek ima samo subalterni događaj, a nikada prapočetak i prema tome uopće nema potpunosti niza na strani uzroka koji potječu jedan od drugoga.

Ni premisa nakon te nije bolja:

(4) Zakon prirode sastoji upravo u tome da se ništa ne događa bez a priori dovoljno određenog uzroka.

Ako pod a priori dovoljno određenim uzrokom Kant misli na vremensko prethođenje, onda ni četvrta premisa nije kompulzivna. Neki kozmološki modeli, primjerice, postuliraju zatvorene vremenske petlje u vrlo ranom svemiru prema kojima će svako stanje svemira biti potpuno objašnjeno prethodnim. Sad, možda

7 Jedna od popularnijih fizikalnih interpretacija kvantne teorije, prema kojoj su kvantni događaji stvarno indeterministički. John Polkinghorne nudi vrlo pristupačan prikaz 6 različitih intepretacija kvantne teorije, s obzirom na to kako odgovaraju na problem mjerenja: 1. irelevantizam, 2. kopenhaška interpretaija, 3. nova fizika (GRW teorija), 4. svijesnosna interpretacija, 5. teorija mnoštva svjetova, 6. determinizam (Polkinghorne, 2002, 46-53). Vidi također: Myrvold, 2016.

8 Zapravo, ne nužno ni po A-teoriji, ako je moguće imati atemporalan uzrok koji započinje temporalan niz. Ili ako „prethodno stanje“ ne mora biti vremenski, nego samo ontički ili logički prethodno. Više o uzročnosti kao ontološkoj ovisnosti vidi: Cohoe, 2013; Kerr, 2012.

9 U svakom slučaju, ni po B-teoriji vremena nije jasno zašto bi „prethodno stanje“ moralo biti vremenski (reducirano na B-teoretske termine vremenske prethodnosti), a ne samo ontološki ili logički prethodno (bilo da ima istu vremensku koordinatu, bilo da je jednostavno atemporalno, bez vremenske koordinate u prostor-vremenskom bloku) te prema zakonima prirode, ali indeterministički uzrokuje ono sljedeće. 
(ispravno) mislite kako to nije vrlo plauzibilno, ali je li to ravno iracionalnosti? Možda i jest, ali je potrebno više argumentativnog posla od puke konstatacije.

Što je s antitezom? Ona glasi: »Nema slobode, nego se sve na svijetu događa samo prema zakonima prirode « i dokaz za nju je:

Pretpostavite da postoji sloboda u transcendentalnome smislu kao posebna vrsta kauzaliteta prema kojemu bi mogli slijediti događaji svijeta, naime da postoji moć da se jedno stanje, a prema tome i niz njegovih posljedica apsolutno započne, onda će započeti ne samo niz pomoću toga spontaniteta, nego i samo određenje toga spontaniteta za proizvođenje toga niza, tj. upravo će kauzalitet započeti, tako da ništa ne prethodi prema čemu je ova radnja koja se događa određena prema pojavnim zakonima. No svaki početak djelovanja pretpostavlja stanje uzroka koji još ne djeluje, a dinamički prvi početak radnje pretpostavlja stanje koje s prethodnim stanjem upravo istog uzroka nema nikakve veze kauzaliteta, tj. koje ni na koji način ne proizlazi iz njega. Dakle, transcendentalna je sloboda suprotna kauzalnome pojmu, a takva veza sukcesivnih stanja djelatnih uzroka, prema kojoj nije moguće jedinstvo iskustva, dakle koja se prema tome ne može naći u iskustvu, jest dakle prazna mišljevina (Kant, 1984, 217-218; A445-447, B473-475).

Kant koristi sljedeće premise:

(1) Ako postoji sloboda volje koja stoji u kauzalnim odnosima, onda će slobodna odluka: 1. započeti novi kauzalni niz i 2 . započeti određenje za proizvođenje novog niza.

Prvi dio konjunkcije konzekvensa čini se očito istinitim. Kauzalni niz koji započinjem slobodnom odlukom podizanja svoje ruke potpuno je drukčiji niz od onoga kojeg bih započeo da sam odlučio nasilno udariti nogom o svoj stol. No drugi dio konjunkcije nije sasvim jasan. Što Kant misli kada kaže da slobodna odluka započinje »određenje za proizvođenje novoga niza «?

Na sreću odmah to pojašnjava: »tj. upravo će kauzalitet započeti, tako da ništa ne prethodi prema čemu je ova radnja koja se događa određena prema pojavnim zakonima«. Čini se kako ima na umu ovo: slobodna odluka će započeti 1. novi kauzalni niz i 2. neće biti determinirana prethodnim stanjima stvari — u smislu da je u istoj situaciji drukčija odluka bila moguća za slobodnog djelatelja. To se tipično razumijeva pod libertarijanskom slobodom. Sljedeća je premisa problematična:

(2) Svaki početak djelovanja pretpostavlja stanje uzroka koji još ne djeluje.

Međutim — ako misli na vremensko prethođenje — za to postoje protuprimjeri. Barem u slučaju Boga, ako posjeduje libertarijansku slobodu i ako je analiza početka postojanja svijeta iz odgovora na prvu antinomiju ispravna, slijedi da Bog slobodno djeluje bez prethodnog vremenskog stanja u kojem još ne djeluje.

Ono što je nužno za libertarijansku slobodu nije postojanje stanja uzroka koji još ne djeluje, nego da uzrok nije determiniran stanjima izvan sebe, tako da je u istoj situaciji mogao izabrati drukčije. Zato ni njegov argument za tezu nije racionalno kompulzivan. Osim toga, ideja da je »transcendentalna sloboda prazna mišljevina« pretpostavlja Kantovu epistemologiju. Ako je skolastička (ili bilo koja druga) epistemologija ispravna, onda transcendentalna sloboda nije prazna mišljevina samo zato što se »ne može pronaći u iskustvu«. Ali Kantovu epistemologiju tek treba dokazati. Stoga se čini da imamo i poročni krug. 


\section{5. Četvrta antinomija: Nužno biće u svijetu (ili izvan svijeta)}

Teza posljednje antinomije glasi: »Svijetu pripada nešto što je ili kao njegov dio ili kao njegov uzrok upravo nužno biće.« Dokaz je:

Osjetilni svijet kao cjelina svih pojava sadržava ujedno niz promjena. Jer bez ovih promjena ne bi nam bila dana čak ni sama predodžba vremenskoga niza kao uvjeta mogućnosti osjetilnoga svijeta. No svaka promjena stoji pod svojim uvjetom koji joj u vremenu prethodi i pod kojim je nužna. Svaka uvjetovana stvar koja je dana pretpostavlja, međutim, u pogledu svoje egzistencije potpuni niz uvjeta do onoga što je potpuno neuvjetovano i jedino apsolutno nužno. Mora dakle da egzistira nešto apsolutno nužno, ako njegova promjena egzistira kao njegova posljedica (Kant, 1984, 221; A452, B480).

Jednostavnosti radi, ostavljamo po strani drugi dio argumenta o tome da je nužno biće dio svijeta; dovoljno je pokazati da prvi dio argumenta nije kompulzivan.

Čini se kako Kant tu formulira nešto poput leibnizovoskog argumenta iz kontingencije. Leibniz je slavno tvrdio kako svaka stvar koja postoji, svaki događaj i svaki istiniti iskaz ima dovoljan razlog zašto postoji ili zašto je takav, a ne drukčiji. Temeljem toga argumentira da je svijet kontingentan i da razlog postojanja kontingentnog svijeta mora biti u metafizički nužnom biću. Kantov je argument sličan i možemo ga ocrtati na sljedeći način:

a) Osjetilni svijet sadrži niz promjena.

a. jer bez promjena ne bismo imali predodžbu vremenskoga niza.

i. jer vremenski niz je uvjet mogućnost osjetilnoga svijeta.

b) Promjene su moguće samo pod uvjetom vremenski prethodnog stanja iz kojeg nužno slijede.

c) Svaka tako uvjetovana stvar ima potpuni niz uvjeta koji objašnjavaju njezinu egzistenciju.

d) Taj niz uvjeta seže do onoga što je potpuno neuvjetovano i jedino apsolutno nužno.

e) Dakle, postoji apsolutno nužno biće.

Ovo nije najsretnija formulacija argumenta iz kontingencije (»uvjetovanosti«) jer (d) je otvoren humovskom napadu: svako stanje potpuno objašnjava sljedeće i postoji beskonačan niz stanja. U tom slučaju svaka uvjetovana stvar može imati potpuni niz uvjeta koji objašnjavaju njezinu egzistenciju, ali taj niz uvjeta neće sezati do potpuno neuvjetovanog i jedino apsolutno nužnog bića. Svako pojedino stanje bit će potpuno objašnjeno i neće biti potrebe za objašnjenjem izvan (beskonačnih) stanja svijeta. Bolja formulacija takve vrste argumenta bila bi sljedeća: ${ }^{10}$

a) Bilo koja stvar koja postoji ima objašnjenje svojeg postojanja, ili u nužnosti vlastite naravi ili u izvanjskom uzroku.

b) Ako svemir ima objašnjenje svojeg postojanja, to objašnjenje je Bog. 
c) Svemir postoji.

d) Dakle, svemir ima objašnjenje svojeg postojanja.

e) Dakle, objašnjenje postojanja svemira je Bog.

Tvrdnja da su sva stanja objašnjena prethodnim u toj formulaciji nije relevantna, jer u argumentu ne izabiremo neko stanje stvari u svemiru i potom se pitamo za njegovo objašnjenje, pa potom za objašnjenje prethodnog itd., nego pitamo za objašnjenje svih stanja stvari zajedno — čitavog svijeta koji postoji; pitamo za objašnjenje ovog mogućeg svijeta.

Čak i da je svijet beskonačan i objašnjen kao što humeovac predlaže, svejedno se možemo pitati zašto postoji takav svemir, a ne drukčiji, ili čak nikakav? Jedini je način da se gornji model spasi i odgovori na to pitanje taj da se kaže da je takav svemir nužan. Ali taj odgovor nije zadovoljavajuć i ima vrlo neuvjerljive posljedice, poput nužnosti mojeg postojanja u sadašnjem trenutku. Sve u svemu, to je obećavajuć argument, no mogu li tvrditi da je Kantova formulacija kompulzivna? Ne na temelju onoga što je dostupno u Kritici.

Antiteza četvrte antinomije glasi: »Ni u svijetu ni izvan njega ne egzistira biće, koje je upravo nužno kao njegov uzrok « i dokaz je:

Pretpostavite da je sam svijet nuždan, ili da je u njemu sadržano neko nužno biće, onda će u nizu njegovih promjena postojati ili početak, koji je bezuvjetno nuždan, dakle bez uzroka, a to proturječi dinamičkome zakonu određenja svih pojava u vremenu, ili je pak sam taj niz bez svakoga početka, a u cijelosti ipak upravo nuždan i neuvjetovan, premda je u svim svojim dijelovima slučajan i uvjetovan, a to opet proturječi samome sebi jer opstojnost jednoga mnoštva ne može biti nužna kad ni jedan jedini njegov dio nema o sebi nužne opstojnosti. Pretpostavite, naprotiv, da ima upravo nuždan uzrok svijeta izvan njega, onda bi on tek kao najviši član u nizu uzroka svjetskih promjena započeo opstojnost tih promjena i njihov niz. No onda bi on morao i započeti djelovati, a njegov kauzalitet pripadao bi vremenu, ali upravo zato i skupu pojava, tj. svijetu, dakle on sam, uzrok, ne bi bio izvan svijeta, a to proturječi pretpostavci. Dakle nema upravo nužnoga bića ni u svijetu ni izvan njega (ali u kauzalnoj vezi s njime) (Kant, 1984, 221-222; A453-455, B481-483).

Premise bi bile:

(1) Ako je svijet nužan, onda ili postoji nužni početak bez uzroka ili je svijet bez početka i potpuno nužan.

Kant razumije da nužne stvari ne mogu početi ni prestati postojati, nego su vječne i neuzrokovane. Imajući to na umu, identificira dvije mogućnosti: ili postoji nužan uzrok svijeta ili je sam svijet nužan. Problem je u sljedećem koraku:

(2) Ako postoji nužan uzrok svijeta, to proturječi dinamičkomu zakonu određenja svih pojava u vremenu.

Ali što čini »dinamički zakon određenja svih pojava u vremenu« kompulzivnim? Ako je uzrok svijeta nužan, onda se jednostavno dinamički zakon neće primjenjivati na njega. Samo reći da to proturječi nekomu zakonu ne pomaže potreban je argument zašto bi to bilo nemoguće. Ali takav argument nigdje ne nalazimo. U svakom slučaju, Kant nastavlja:

(3) Ako je sam svijet nužan, onda su i njegovi dijelovi nužni.

(4) Njegovi dijelovi nisu nužni. 
Spinozist bi mogao prosvjedovati protiv (4); prema njemu sve u svijetu jest nužno. Kant bi morao argumentirati protiv toga: možda bi se mogao pozvati na naše modalne intuicije o svijetu i osnažiti ih neovisnim argumentima, ali to ne čini. Okreće se mogućnosti nužnog objašnjenja izvan svijeta:

(5) Ako postoji nužan uzrok izvan svijeta, onda je on samo najviši član u nizu uzroka koji započinje postojanje svijeta.

(6) Ako je on samo najviši član takvog niza, onda i on sam započinje svoje djelovanje.

(7) Ako on započne svoje djelovanje, onda nije izvan svijeta — što proturječi pretpostavci.

Čini se da Kant ne referira na istu stvar sa „svijet“ u premisama (3) i (4) s jedne te (5)-(7) s druge strane. U prvom slučaju, „izvan svijeta“ trebalo bi značiti samo „takvo da nije dio prirodnog poretka“; da „ne potpada pod prirodne zakone“, nego da je „transcendentno svijetu materije, energije itd.“ Ali u drugom slučaju čini se da Kant termin „svijet“ koristi kao „mogući svijet“; odnosno totalni opis ili niz svih istinitih iskaza o svijetu. Sad, nužno biće koje je izvan „Svijeta“ u prvom značenju i njegov uzrok (Bog) neće samo biti dio svijeta - to bi bilo nekoherentno. Ali bit će dio „svijeta“ u drugom značenju. No, to nije problematično jer se termin „svijet“ koristi na različite načine u argumentu i stoga nema proturječja pretpostavci.

Nijedan teist neće reći da Bog ne postoji u ovom mogućem svijetu, ali će inzistirati na tome kako Bog nije dio ovog svijeta u smislu da nije kontingentno biće, ne ulazi u sastav prirodnog svijeta i ne potpada pod prirodne zakone itd.

Alternativno, ako Kant koristi termin „svijet“ univočno u svim premisama, u značenju „prirodni svijet“, onda je nejasno zašto bi premisa (7) bila istinita. Čak i da Božje djelovanje u uzrokovanju svijeta implicira njegov ulazak u temporalan (ili bilo kakav drugi) odnos sa svijetom, ne slijedi da Bog nije „izvan svijeta“ u smislu da je biće neovisno od svijeta koje ima uzročnu moć stvoriti ga.

Kant opravdava (7) tako što tvrdi da ako je nužno biće »uzrok izvan svijeta«, onda je ono samo »najviši član u nizu uzroka svjetskih promjena«, što povlači da je »započeo djelovati«, što povlači »pripadanje vremenu«, što pak povlači »pripadanje svijetu «.

Čini se da je svaki od tih koraka kontroverzan. Recimo da nužno biće u pitanju uzrokuje svijet atemporalno, odjednom i oduvijek. U tom smislu „započeti djelovati“ ne povlači „pripadanje vremenu.“ Koji argument nalazimo za iracionalnost toga?

Ili recimo da nužno biće u nekom smislu doista „pripada vremenu“. Povlači li to da „pripada svijetu“ na način kao druge kontingentne stvari kojima treba objašnjenje ili uzrok? Teško. Ako s Newtonom mislite da Božji atribut vječnosti konstituira vrijeme (Newton, 1966, 2:545) onda će Bog oduvijek „pripadati vremenu“, ali neće „pripadati svijetu“ u smislu „biti jedna od kontingentnih stvari koja treba objašnjenje/uzrok“. Koji argument nalazimo za iracionalnost toga?

Mislim da poprilično opravdano možemo zaključiti: nijedan dio antiteze, kako stoji, nije ni blizu toga da se nameće po cijenu racionalnosti. 


\section{Zaključak}

Predložio sam da je za tako egzotično stajalište kao što je uobičajena interpretacija Kantove epistemologije (UIKE) — imamo spoznajni pristup samo fenomenima, ne možemo referirati na stvari po sebi — potrebno neko moćno opravdanje, razlog zašto prihvatiti gledište koje je protivno dobromu dijelu garniture naših svakodnevnih i zdravorazumskih vjerovanja. Predložio sam zatim da bi antinomije iz Kritike čistoga uma mogle biti takvo opravdanje. Ako bismo pod pretpostavkom realistične epistemologije (ne-transcendentalni-idealizam) dobili racionalno kompulzivna proturječja, morali bismo zanijekati pretpostavku i zaključiti na transcendentalni idealizam. Antinomije bi, prema tome, bile važan dio UIKE-a bez kojeg, uvjerljivo, nema opravdanja — čak i da se zanemare problemi koherencije.

Da bi UIKE dobila na opravdanosti, barem jedna antinomija mora biti racionalno kompulzivna - takva da je i teza i antiteza dokazana i da bi negiranje ijedne povlačilo iracionalnost. Međutim, nijedna od antinomija nije takva: neke od teza i antiteza u najboljem slučaju može se klasificirati kao dobre argumente, ali ne kao racionalno kompulzivne, barem ne na temelju onoga što pronalazimo kod Kanta u Kritici čistoga uma. Zato zaključujem: (1) plauzibilno, UIKE je nekoherentna, (2) UIKE nije opravdana antinomijama i (3) ako su antinomije jedino opravdanje za UIKE, onda UIKE nije opravdana. ${ }^{11}$

\section{Literatura:}

Abian, Alexander (1965). The Theory of Sets and Transfinite Arithmetic. Philadelphia: Saunders.

Cohoe, Caleb (2013). There must be a First: Why Thomas Aquinas Rejects Infinite, Esssentially Ordered, Causal Series. The British Journal for the History of Philosophy, $21,5,838-56$.

Craig, William Lane (1979). The Kalām Cosmological Argument. Eugene, Oregon: Wipf and Stock.

Craig, William Lane (2007). The Metaphysics of special relativity: Three Views. U: William Lane Craig i Quentin Smith (ur.), Einstein, Relativity and Absolute Simultaneity (str. 11-49). New York: Routledge.

Craig, William Lane (2008). Reasonable Faith: Christian Truth and Apologetics. Wheaton, Illinois: Crossway.

Juko, Hrvoje; Renić, Dalibor (2015). Pojam kontingencije u argumentima za Božju opstojnost Tome Akvinskoga i G. W. Leibniza. Obnovljeni život, 70, 2, 163-179.

Kant, Immanuel (1984). Kritika čistoga uma. Zagreb: Nakladni zavod Matice hrvatske.

11 Važna napomena: pretpostavljam da je teza o transcendentalnoj idealnosti predmeta naše spoznaje bitan dio Kantove (i bilo koje kantolike) epistemologije, pa stoga i UIKE-a. Ako bi moglo biti neke kantolike epistemologije bez teze o transcendentalnoj idealnosti, onda bi (2) i (3) morali lagano oslabiti, tako da se odnosi na UIKE+tezu o transcendentalnoj idealnosti. Ali ne vidim da bi moglo biti kantolike epistemologije dostojne tog imena bez teze o transcendentalnoj idealnosti predmeta naše spoznaje. 
Kerr, Gaven (2012). Essentially Ordered Series Reconsidered. American Catholic Philosophical Quarterly, 86, 4, 541-55.

Mackie, John Leslie (1982). The Miracle of Theism. New York: Oxford University Press.

Myrvold, Wayne (2016). Philosophical Issues in Quantum Theory. U: The Stanford Encyclopedia of Philosophy. URL: https://plato.stanford.edu/entries/qt-issues/ (20.06.2017.)

Newton, Isaac (1966). Sir Isaac Newton's Mathematical Principles of Natural Philosophy and His System of the World. Los Angeles: University of California Press.

Plantinga, Alvin (2000). Warranted Christian Belief. New York: Oxford University Press.

Polkinghorne, John (2002). Quantum Theory: A Very Short Introduction. New York: Oxford University Press.

Sobel, Jordan Howard (2004). Logic and Theism: Arguments For and Against Beliefs in God. Cambridge: Cambridge University Press.

Stang, Nicholas F. (2016). Kant's Transcendental idealism. U: The Stanford Encyclopedia of Philosophy. URL: https://plato.stanford.edu/entries/kant-transcendental-idealism/ (20.06.2017).

Swinburne, Richard (1968). Space and Time. London: Palgrave Macmillan.

A Critique of Antinomies as Justification for the Usual Interpretation of Kant's Epistemology

Hrvoje Juko*

\section{Summary}

The transcendental ideality of the objects of cognition is an essential part of Kant's epistemology - at least, in its usual interpretation. In this article, the author proposes that (precisely because of the transcendental ideality thesis), the usual interpretation of Kant's epistemology (UIKE) suffers from problems of incoherence, and plausibly so, and so is not clearly justified. In response to the suggestion that antinomies justify UIKE, the author claims that at least one antinomy should then be rationally compulsive, however, not one of them is. The author, therefore, concludes that antinomies do not justify UIKE and, that if antinomies are the only justification for UIKE, then it is not justified.

Key words: Immanuel Kant, Critique of Pure Reason, transcendental idealism, usual interpretation of Kant's epistemology, antinomies, rational compulsivity, justification

* Hrvoje Juko, univ. bacc. phil, Pontifical Gregorian University. Address: Piazza della Pilotta 4, 00187 Rome, Italy. E-mail: hrvoje_juko@yahoo.com 